\title{
OCCURRENCE OF UROLITES RELATED TO DINOSAURS IN THE LOWER CRETACEOUS OF THE BOTUCATU FORMATION, PARANÁ BASIN, SÃO PAULO STATE, BRAZIL
}

\author{
MARCELO ADORNA FERNANDES \\ Programa de Pós-graduação em Geologia, UFRJ, Av. Brigadeiro Trompowski, s/n, Ilha do Fundão, \\ 21949-900, Rio de Janeiro, RJ, Brasil.marcelicno@yahoo.com.br \\ LUCIANA BUENODOS REIS FERNANDES \\ Programa de Pós-graduação em Ecologia e Recursos Naturais, UFSCar, Rua Imaculada Conceição, 2383, \\ 14801-400, Araraquara, SP, Brasil. lucianabrfernandes@yahoo.com.br \\ PAULO ROBERTODE FIGUEIREDO SOUTO \\ Departamento de Geologia, UFRJ, Av. Brigadeiro Trompowski, s/n, Ilha do Fundão, \\ 21949-900, Rio de Janeiro, RJ, Brasil.paulosouto@ig.com.br
}

\begin{abstract}
The geological units that correspond to the Mesozoic in the Paraná basin, São Paulo State, are included in São Bento Group, by correlation with the Pirambóia, Botucatu and Serra Geral formations. The Botucatu Formation's age is bracketed between the Upper Jurassic and the Lower Cretaceous (Neocomian). The Botucatu Formation is composed of aeolian sandstones showing cross-stratification from medium to large scale, a typical trait of migrating dunes. Ichnofossils were collected in the São Bento Quarry, located in the city of Araraquara, São Paulo State. Samples MPA-002 e MPA-003, respectively, are the negative epirelief and positive hyporelief of the same trace fossil. MPA-001 is a negative epirelief. These features show a removal of sedimentary material, in contrast to the morphology of ornithopod and theropod dinosaur tracks, where compression and deformation of unconsolidated sedimentary layers occurs. These trace fossils show a pattern corresponding to erosion caused by evacuation of liquid wastes and are classificated as urolites, because this term has already been applied to the occurrence of ichnofossils of this type in France and Germany. The morphostructure of these urolites is very similar to the erosional geometry produced in the substrate by expelled liquid waste of modern ratite birds, such as Struthio camelus (ostrich). These urolites are the first records in Brazil of this type of ichnofossil, and is also one of the first examples of trace fossils attributed to liquid waste expulsion by dinosaurs.
\end{abstract}

Key words: urolite, vertebrate ichnofossils, Botucatu Formation, Cretaceous.

RESUMO - As unidades geológicas que correspondem ao Mesozóico da Bacia do Paraná, no Estado de São Paulo, estão reunidas no Grupo São Bento, pela associação das formações Pirambóia, Botucatu e Serra Geral. A idade da Formação Botucatu se estende do final do Jurássico ao início do Cretáceo (Neocomiano). A Formação Botucatu é constituída por arenitos eólicos exibindo estratificação cruzada de médio a grande porte, característica de dunas transladantes. Os icnofósseis foram coletados na Pedreira São Bento, localizada no município de Araraquara, no Estado de São Paulo. As amostras MPA-002 e MPA-003 são respectivamente o epirrelevo negativo e o hiporrelevo positivo de um mesmo icnofóssil. O exemplar MPA-001 é um epirrelevo negativo. Existe remoção de material sedimentar contrastante com a morfologia das pegadas de dinossauros Ornithopoda e Theropoda, onde ocorre a compactação das camadas sedimentares e crenulações, com deformação do sedimento inconsolidado. Os icnofósseis apresentam o padrão correlacionável ao de extrusões líquidas como produtos de evacuação e são classificados como urólitos, pois esse termo já foi empregado para ocorrência de icnofósseis desta categoria na França e na Alemanha. O aspecto morfoestrutural destes urólitos é muito semelhante à deformação causada no substrato por extrusões líquidas de aves ratitas atuais, como Struthio camelus (avestruz). Estes urólitos são os primeiros registros no Brasil deste tipo de icnofóssil, sendo também uma das primeiras evidências do modo de extrusão líquida associada a dinossauros.

Palavras-chave: urólito, icnofósseis de vertebrados, Formação Botucatu, Cretáceo.

\section{INTRODUCTION}

The first fossil records from Botucatu Formation were made by a Brazilian mine engineer, Joviano Pacheco in 1913. However, only Huene (1931) studied and interpreted these fossil records as being invertebrate and vertebrate ichnofossils associated with a desert environment. Many isolated footprints and tetrapod tracks are present in the Botucatu paleodesert ichnocoenosis, and among them are ornithopod and theropod dinosaurs. 
The first evidence of occurrence of liquid waste elimination attributed to a dinosaur was presented to the public during the $62^{\text {nd }}$ Congress of the Vertebrate Paleontological Society from North America in Oklahoma, in the United States, by McCarville \& Bishop (2002) from the Museum of Geology, at the South Dakota School of Mines and Technology. The discovery was reported in some e-magazines by Reed (2002), Leblanc (2002) and Rivieccio (2002), in which they related the discovery of traces of liquid waste associated with sauropod dinosaurs in a locality of La Junta, Colorado, USA. This locality is known as a significant tracksite recording activities of dinosaurs of the Morrison Formation and is an important paleoichnological site in North America.

The trace fossils studied were collected in São Bento Quarry, located in Araraquara, São Paulo State, at the coordinates $21^{\circ} 49^{\prime} \mathrm{S}$ and $48^{\circ} 04^{\prime} \mathrm{W}$ (Figure 1). The quarry produces flagstones used to pave sidewalks and as wall covering. Many flagstones with vertebrate and invertebrate ichnofossils were examinated by Leonardi (1980, 1981, 1984), Leonardi \& Sarjeant (1986), Leonardi \& Oliveira (1990), Fernandes et al. (1990) and Leonardi \& Carvalho (2002). Until the present work, no scientific paper had been reported a fossil evidence of liquid waste of tetrapods elimination, from Botucatu Formation or anywhere else, to assume that dinosaurs urinated.

\section{GEOLOGICAL SETTING}

The Paraná basin is a typical cratonic basin located on the rigid lithosphere in the southest part of the Brasilian Platform in an area deeply affected by the lava outflow of the Brazilian Cycle. It has an irregular oval shape and covers an area of about $1,500,000 \mathrm{~km}^{2}$. The deposicional axis of the Paraná basin parallels the Paraná River, where the basin fill attains a thickness of 5,000 m. This basin includes Devonian and Upper Paleozoic continental and marine clastic sedimentary sequences. The Upper Paleozoic sequence represents a glacial environment at its beginning and fluviallacustrine at its end. These units were covered by an Upper Jurassic to Early Cretaceous continental sedimentary sequence deposited in a semi-arid environment and flood basalts associated with the most widespread global episode of continental basic volcanism (Loczy \& Ladeira, 1976).

The Mesozoic Period in São Paulo State is represented by the São Bento Group containing the Pirambóia, Botucatu and Serra Geral formations. The Botucatu Formation is mostly intercalated with the Serra Geral basalt and its age is indicated by stratigraphic relationships rather than by fossils. Bigarella \& Salamuni (1961) suggest that the aeolian sandstones would have been accumulated between the Late Jurassic and Early Cretaceous. According to Scherer et al. (2000), the upper limit of the Botucatu Formation's age corresponds to the Neocomian, contemporaneous with the most recent lava flows of the Serra Geral Formation. ${ }^{40} \mathrm{Ar} /{ }^{39} \mathrm{Ar}$ dating by Renne et al. (1992) and Turner et al. (1994) shows that the volcanic rocks of Serra Geral Formation are about 132 million years old.

According to Fúlfaro \& Petri (1988), the Botucatu Formation is composed primarily of fine to medium-grained reddish well-sorted sandstones with abundant opaque grains of high sphericity. These sandstones show tangential crossstratification as is characteristic of migrating dunes. The Botucatu sandstone covers most of Paraná basin in Brazil, Eastern Paraguay and Northest Argentina, covering an area

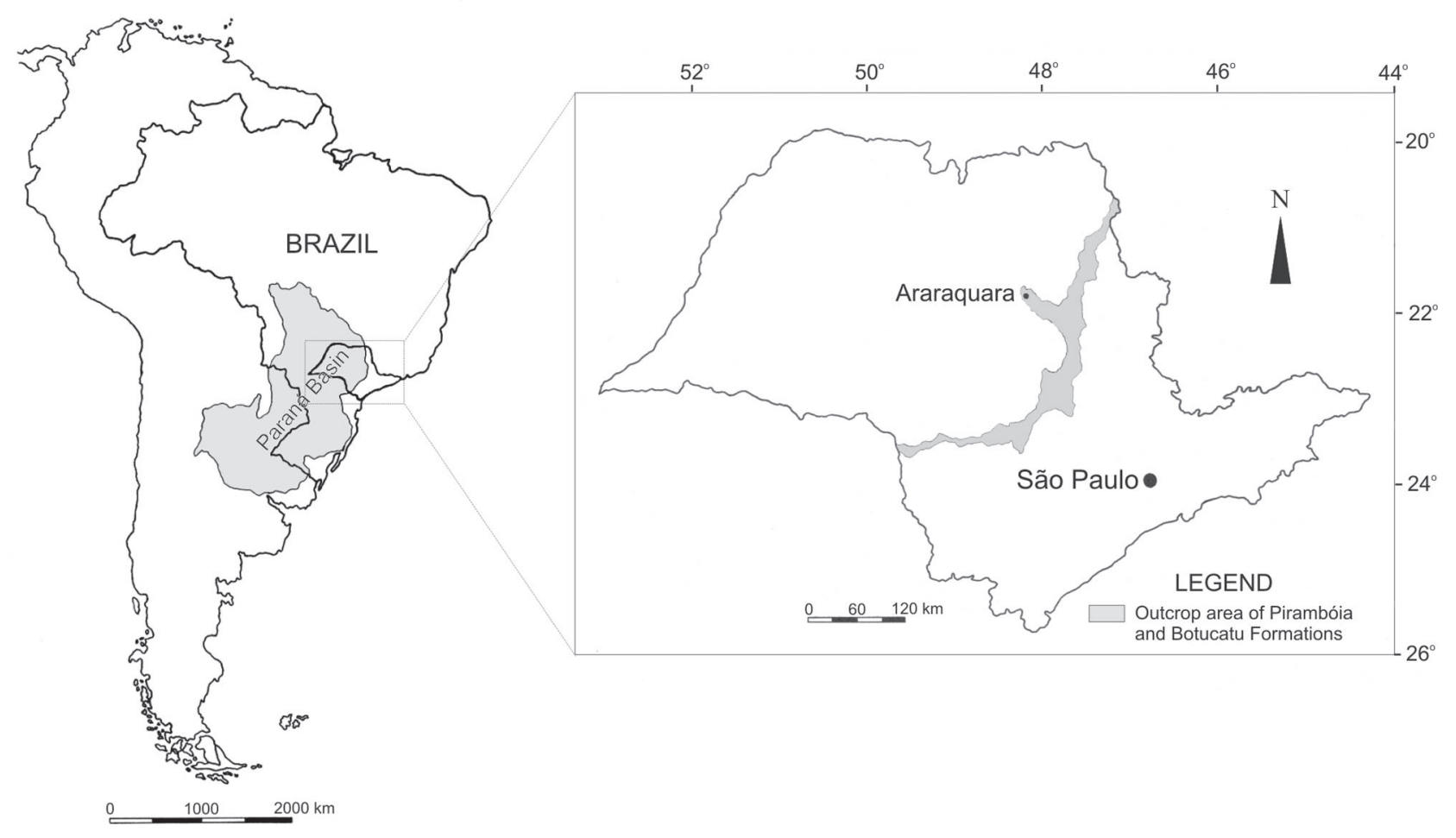

Figure 1. Location map of Paraná basin in South America and the outcrop area of Pirambóia and Botucatu formations in São Paulo State. 

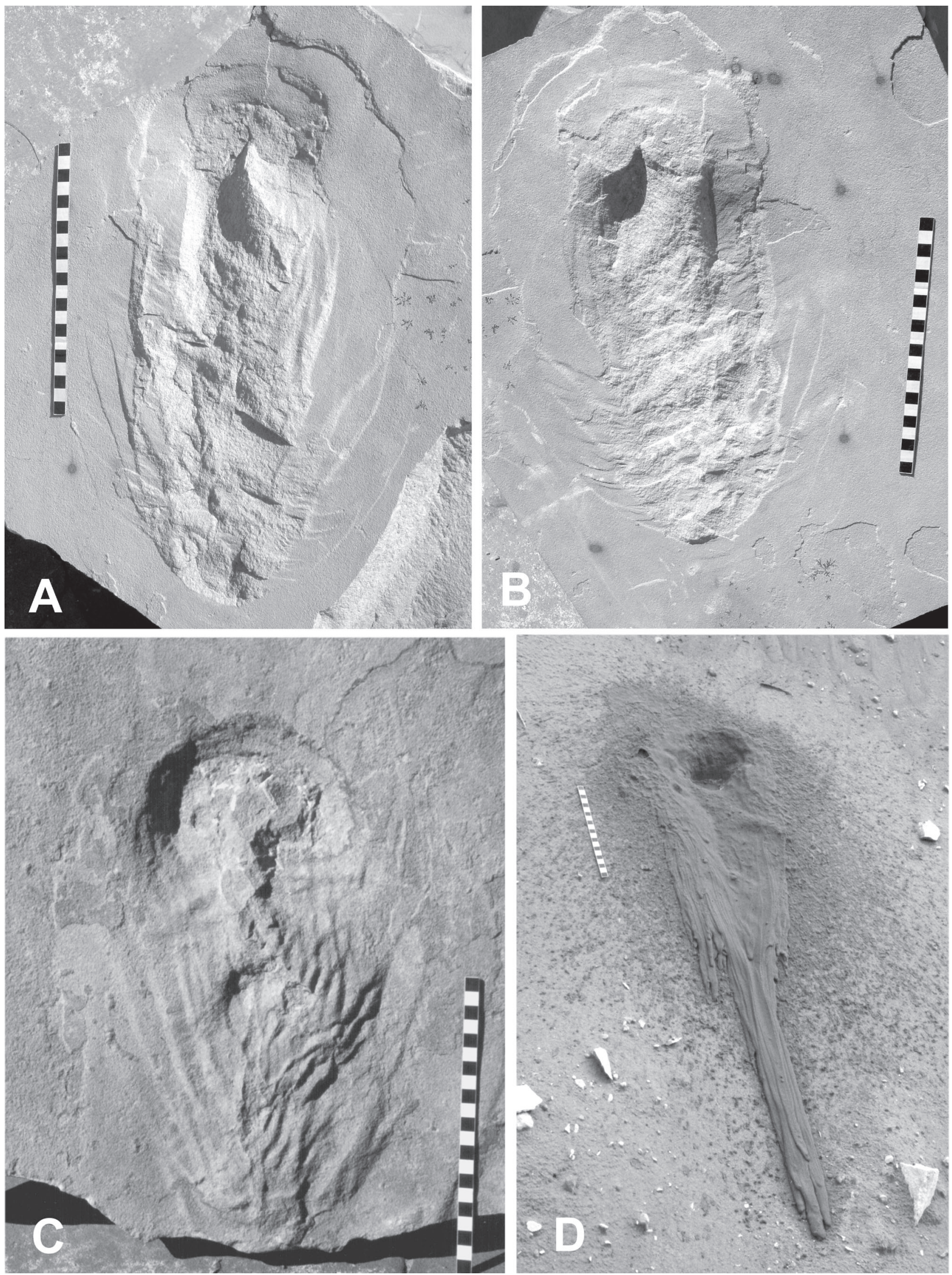

Figure 2. Trace fossils corresponding to liquid wastes. A. Sample MPA-002, a negative epirelief; B. Sample MPA-003, a positive hyporelief; C. Sample MPA-001, a negative epirelief; D. Excavation structure formed by two liters of water in a simulated test. Scale bar in centimeters. 
of more than $1,300,000 \mathrm{~km}^{2}$. Deposits of the Botucatu Formation constitute a record of aeolian deposition in desert conditions including persistent ergs and wadi deposits (Soares, 1975; Schneider et al., 1974; Caetano-Chang \& Wu, 1992). According to Bigarella \& Salamuni (1961), the wind that moved the dunes in the Botucatu paleodesert in São Paulo State originally blew from N to NE. The most typical sedimentary structures are the tangential cross-stratifications. An angular unconformity marks the lower contact of the Botucatu Formation with the basement and the Paleozoic formations. With the Pirambóia Formation, this contact may be conformable in some places. According to Scherer (1998), the basalt of the Serra Geral Formation overlays conformably on the Botucatu Formation. In some parts of the basin the aeolian sediments are intermixed with the lava flows showing that the volcanism was contemporaneous with aeolian deposition.

Intrusive diabase dikesandsills throughout the sedimentary section of the basin are correlated to the Serra Geral Formation. The Pirambóia Formation and its correlative deposits represent fluvial deposition at the time of the continentalization of Paraná basin in the Triassic, forming an unconformity surface associated with a period of erosion that occurred between the Triassic and the Jurassic. A new period of deposition began with the aeolian sandstones of the Botucatu Formation and its correlates, overlain by volcanic rocks of the Serra Geral Formation (Almeida \& Melo, 1981).

\section{TERMINOLOGY}

According to Fernandes et al. (2002), a trace fossil is a distinct biogenic structure and shows a behavioural function which can be closely related to the morphology of the organism which has produced it, such as footprints, tracks, excavations also including coprolites, fecal pellets and other fossil structures.

The term "coprolite" is generally applied to all types of fossil excrement (Sarjeant, 1975). The expression "urolite" was

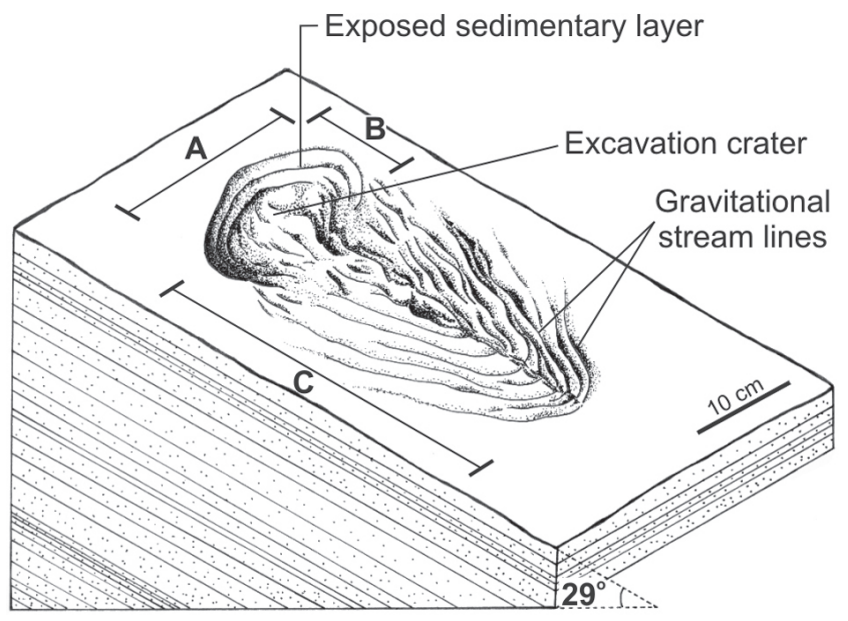

Figure 3. Diagram representing a urolite in a non-horizontal surface at the paleodune foreset. A. Major axis; B. Minor axis; C. gravitational stream caused by sand fluidization. first used in France by Duvernoy (1844) to differentiate the fossil nonliquid urinary secretions, produced by some groups of reptiles, in relation to coprolites. Leydig (1896a,b) identified urolites produced by icthyosaurs in sediments of the Triassic, in Germany. Voigt (1960) described urolites formed of apatite and calcite produced by reptiles from the Upper Cretaceous in Germany. McCarville \& Bishop (2002) mention the discovery of a trace fossil formed by expulsion of liquid waste associated with sauropod dinosaurs in the Morrison Formation, in the United States, but they did not suggest any specific terminology to name the bioturbation structure produced by fluid stream. Since the term urolite was adopted to determine fossilized nonliquid urinary secretions (like those expelled by reptiles or birds), we think this term (compound of two Greek words, uro meaning "urine" and lithos meaning "stone") is the most appropriate to determine the trace fossil formed by evacuation of liquid waste of a dinosaur or any other vertebrate.

\section{DESCRIPTION OF TRACE FOSSILS AND DISCUSSION}

The trace fossils examined in this study are reposited in a newly organized local museum, the Museum of Paleontology in Araraquara (MPA). The studied trace fossils are preserved in three aeolian flagstones: MPA-001 (75x45 cm), MPA-002 $(50 \times 45 \mathrm{~cm})$ and MPA-003 $(60 \times 50 \mathrm{~cm})$. The samples MPA-002 and MPA-003 respectively are the negative epirelief and positive hyporelief of the same trace fossil (Figures 2A, B). The exemplar MPA-001 is a negative epirelief (Figure 2C). The elliptical morphology of the concave portion in the small excavation crater of MPA-001 is $16 \mathrm{~cm}$ in diameter along the major axis and $11 \mathrm{~cm}$ along the minor axis, and about $1.8 \mathrm{~cm}$ deep. MPA-002 is $19 \mathrm{~cm}$ in diameter along the major axis and $12 \mathrm{~cm}$ along the minor axis and $1.8 \mathrm{~cm}$ deep.

In both specimens, the boundary of the concave structure shows inner concentric delineations corresponding to the sedimentary layers of the foreset that became exposed. The lower edge of the concave structure is overlaid with the sediment removed from there and the sand removed by fluidization formed a gravitational stream of $34 \mathrm{~cm}$ length (Figure 3). Vertically, the foreset dip is $29^{\circ}$.

To understand the formation of this fossil structure, it was simulated by a simple experiment. Two liters of water were poured from $80 \mathrm{~cm}$ height in a sloped area of loose sand. The result was an excavation structure similar to the fossil structures, resulting in the removal of the superficial layers of sand and flowing of the rest by gravity (Figure 2D).

Concerning the formation of these structures, there is a clear withdrawal of sedimentary material compared to the morphology of the associated dinosaur tracks (Figure 4A, B, C), where the sedimentary layers are compressed by the weight of the animal. The dinosaur tracks belonging to the ichnocoenosis of Botucatu Formation are of ornithopod and theropod dinosaurs, always displaying a half-moon shaped ridge on the edge where more effort was made by the motion of these animals in the paleodesert sand. Undertracks do not show this feature. Besides, the shape of the trace fossil is markedly different from the shapes of the associated dinosaur tracks. 

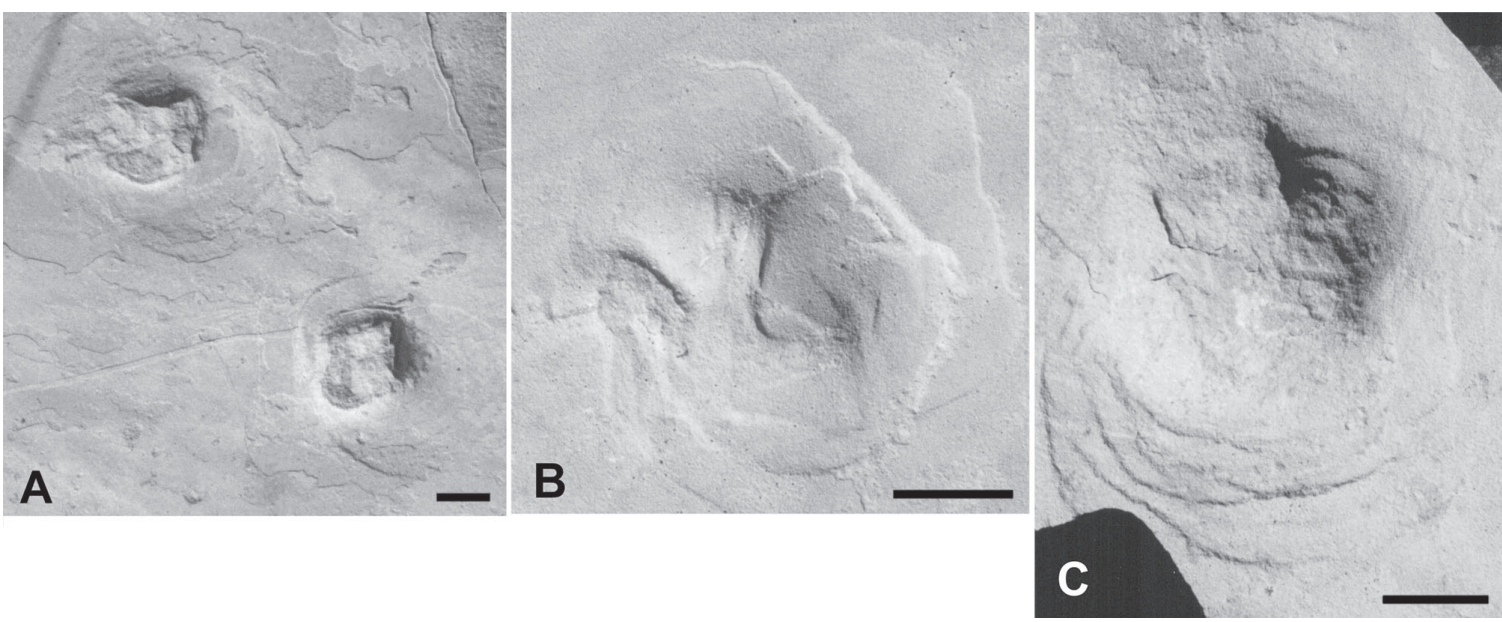

Figure 4. Dinosaur tracks, belonging to the ichnocoenosis of the Botucatu Formation, produced in a foreset dip of $29^{\circ}$. A. Ornithopod dinosaur; B, C. Theropod dinosaurs. Scale bar $=5 \mathrm{~cm}$.
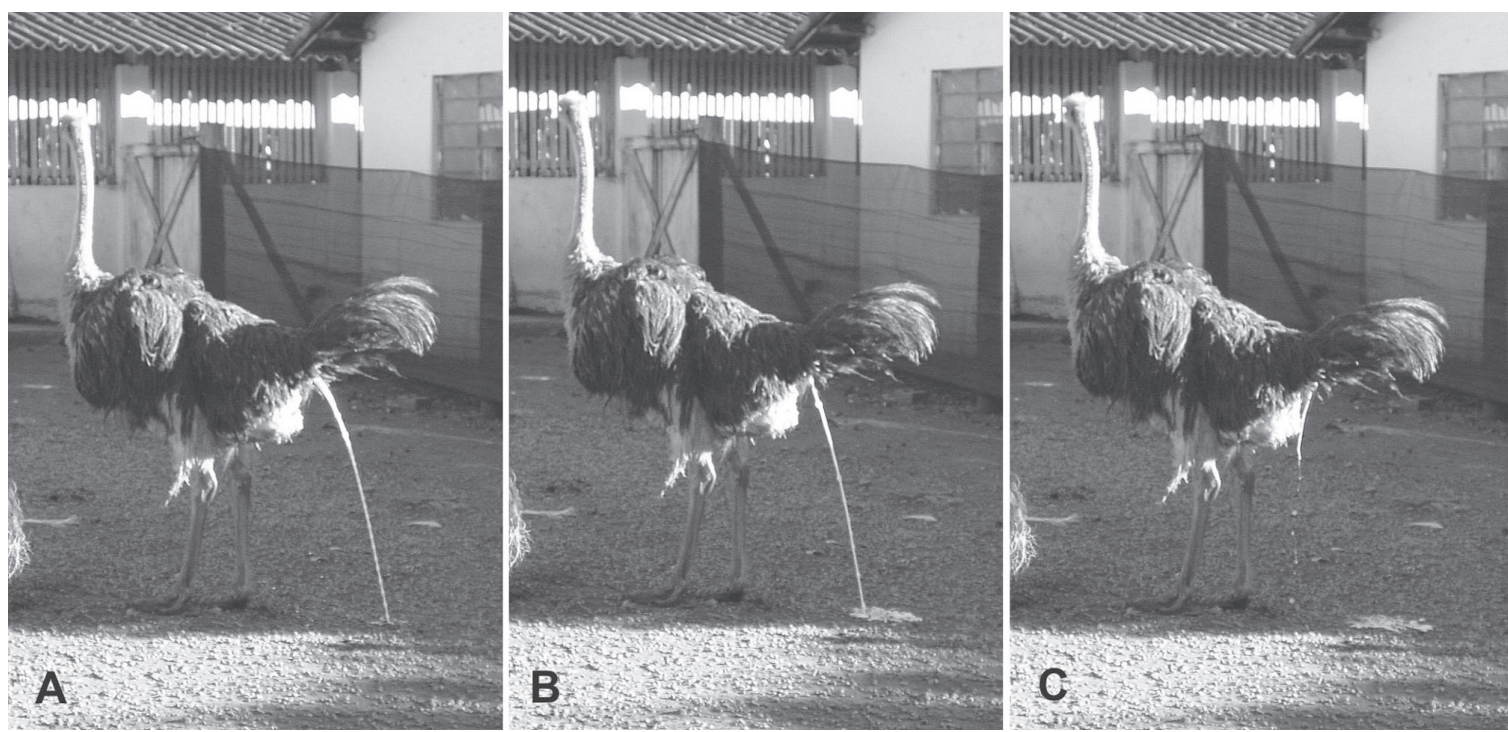

Figure 5. Struthio camelus (ostrich). A, B, C. Sequence of pictures taken at an ostrich farm showing the strong flow of liquid waste produced during evacuation.

Leonardi $(1981,1984,1994)$ documented the presence of several kinds of small mammals, and these could be the source of a liquid waste. However, the size of the trace fossils indicates they would have to be produced by bigger animals, such as ornithopod dinosaurs, which were present as shown by their fossilized tracks.

Comparing and analyzing the behavior of modern ratite birds, such as Struthio camelus (ostrich), we observed a strong flow of liquid waste (urine) produced by these animals (Figure 5A, B, C) before the solid waste evacuation. In ostriches, the urine remains stored in the urodeum, which have similar function to a urinary bladder of mammals, until the moment of its elimination. The solid wastes remains stored in the coprodeum and are eliminated subsequent to the urine (Moro \& Luchini, 1999). Assuming that certain groups of dinosaurs had a similar urinary physiology, they could have caused erosion of unconsolidated sediments on the surface when eliminating an abundant liquid flow similar to that produced by the ostrich.

\section{CONCLUSIONS}

Among the countless vertebrate ichnofossils recorded in the aeolian sandstones of São Bento Quarry in Araraquara, up to now only two trace fossils have been identified as urolites. Despite the documented occurrence of small mammals fossilized tracks in the Botucatu Formation, the trace fossils studied here seem to be produced by bigger animals, like dinosaurs, that existed in the Botucatu paleodesert.

The studied trace fossils show a pattern that we demonstrated could be formed by an abundant falling stream of fluid and that is different from the structures described before in other occurrences in the paleontological records. The morphostructural aspect of these urolites is very similar to the deformation caused in the soil by elimination of liquid wastes of modern ratite birds, like Struthio camelus (ostrich). These urolites are the first records in Brazil of this type of ichnofossil, and it is also one of the first evidences of the liquid waste attributed to dinosaurs. 


\section{ACKNOWLEDGMENTS}

We thank Ismar de Souza Carvalho (Universidade Federal do Rio de Janeiro) for the Ph D. supervision; the Conselho Nacional de Desenvolvimento Científico e Tecnológico (CNPq) for financial support of our research; Oswaldo Grosso and José Francisco Grosso, owners of the São Bento Quarry in Araraquara, for collaboration and access permission to our field research. The authors thank the referees for the critical review and suggestions.

\section{REFERENCES}

Almeida, F.F.M. \& Melo, C. 1981. A bacia do Paraná e o vulcanismo mesozóico. In: C.C. Bistrichi; C.D.R. Carneiro; A.S.L. Dantas \& W.L. Ponçano (eds.) Mapa Geológico do Estado de São Paulo, Instituto de Pesquisas Tecnológicas, 1:46-77.

Bigarella, J.J. \& Salamuni, R. 1961. Early Mesozoic wind patterns as suggested by dune bedding in the Botucatu Sandstone of Brazil and Uruguay. Geological Society of American Bulletin, 72:1089-1106.

Caetano-Chang, M.R. \& Wu, Fu-Tai 1992. Estudo mineralógico dos arenitos das formações Pirambóia e Botucatu no centroleste do Estado de São Paulo. Revista do Instituto de Geociências, 13(1):58-68.

Duvernoy, G. 1844. Sur l'existence des urolithes fossiles, et sur l'utilité que la science des fossiles organiques pourra tirer de leur distinction d'avec lês coprolithes, pour la détermination de restes fossiles de Sauriens et d'Ophidiens. Comptes Rendus Hebdomadaires des Séances de l'Académie des Sciences, 19:255-260.

Fernandes, A.C.S.; Borghi, L.; Carvalho, I.S. \& Abreu, C.J. 2002. Guia dos icnofósseis de invertebrados do Brasil. $1^{\mathrm{a}} \mathrm{ed}$. Rio de Janeiro, Interciência, $260 \mathrm{p}$.

Fernandes, A.C.S.; Carvalho, I.S. \& Netto, R.G. 1990. Icnofósseis de invertebrados da Formação Botucatu, São Paulo, Brasil. Anais da Academia Brasileira de Ciências, 62(1):45-49.

Fúlfaro, V.J. \& Petri, S. 1988. Geologia do Brasil. São Paulo, Universidade de São Paulo, 631 p.

Huene, F. von 1931. Verschiedene mesozoische Wirbeltierreste aus Südamerika. Neues Jahrbuch für Geologie and Paläontologie, Monastshefte, 66(B):181-198.

Leblanc, J. 2002. Quand un dinosaure lève la patte. Cybersciences. http://www.cybersciences.com/cyber/3.0/n2975.asp

Leonardi, G. 1980. On the discovery of an abundant ichno-fauna (vertebrates and invertebrates) in the Botucatu Formation in Araraquara, São Paulo, Brazil. Anais da Academia Brasileira de Ciências, 52(3):559-567.

Leonardi, G. 1981. Novo icnogênero de tetrápode Mesozóico da Formação Botucatu, Araraquara, SP. Anais da Academia Brasileira de Ciências, 53(4):793-805.

Leonardi, G. 1984. Rastros de um mundo perdido. Ciência Hoje, 2(15):48-60.

Leonardi, G. 1994. Annotated atlas of South America tetrapod footprints (Devonian to Holocene) with an appendix on Mexico and Central America. Brasília, CPRM, 248 p.

Leonardi G. \& Carvalho I.S. 2002. Jazigo icnofossilífero do Ouro, Araraquara, SP. In: C. Schobbenhaus; D.A. Campos; E.T. Queiroz; M. Winge \& M.L.C. Berbert-Born (eds.) Sítios Geológicos e Paleontológicos do Brasil, DNPM, CPRM, SIGEP, p. $39-48$.
Leonardi, G. \& Oliveira, F.H. 1990. A revision of the Triassic and Jurassic tetrapod footprints of Argentina and a new approach on the age and meaning of Botucatu Formation footprints (Brazil). Revista Brasileira de Geociências, 20(1-4):216-229.

Leonardi G. \& Sarjeant, W.A.S. 1986. Footprints representing a new Mesozoic vertebrate fauna from Brazil. Modern Geology, 10:73-84.

Leydig, F. 1896a. Koprolithen und Urolithen. Neues Jahrbuch für Geologie and Paläontologie, Monastshefte, 2:139-140.

Leydig, F. 1896b. Koprolithen und Urolithen. Biologisches Centralblatt, 16:101-103.

Loczy, L. \& Ladeira, E.A. 1976. Geologia estrutural e introdução à geotectônica. São Paulo, Edgard Blücher, $528 \mathrm{p}$.

McCarville, K. \& Bishop, G.A. 2002. To pee or not to pee: evidence for liquid urination in sauropod dinosaurs. In: ANNUAL MEETING OF THE SOCIETY OF VERTEBRATE PALEONTOLOGY, 62, 2002. Journal of Vertebrate Paleontology Supplement, 22(3):85.

Moro, M.E.G. \& Luchini, L. 1999. Anatomia, fisiologia e sanidade. In: C.C. Carrer \& M.E. Kornfeld (orgs.) A criação de avestruzes no Brasil, Brasil Ostrich, p. 57-65.

Pacheco, J.A.A. 1913. Notas sobre a Geologia do Valle do Rio Grande a partir da foz do Rio Pardo até a sua confluência com o Rio Parahyba. In: Comissão Geográfica e Geológica do Estado de São Paulo. Exploração do Rio Grande e de seus afluentes, São José dos Dourados, p. 33-38.

Reed, C. 2002. A dinosaur's wasted legacy. Geotimes. http:// www.agiweb.org/geotimes/dec02/NN_dinowaste.html

Renne, P.R.; Ernesto, M.; Pacca, I.G.; Coe, R.S.; Glen, J.; Prevot, M. \& Perrin, M. 1992. The age of Paraná flood vulcanism, rifting of Gondwanaland, and the Jurassic-Cretaceous boundary. Science, 258:975-979.

Rivieccio, G. 2002. Scoperto un cratere fossile di pipì di dinosauro. Newton. http://www.newton.rcs.it/PrimoPiano/News/2002/ 10_Ottobre/30/Dinopipi.shtml

Sarjeant, W.A.S. 1975. Fossil tracks and impressions of vertebrates. In: R.W. Frey (ed.) The study of trace fossils, Springer, p. 283324.

Scherer, C.M.S. 1998. Análise estratigráfica e litofaciológica da Formação Botucatu (Neocomiano) no Estado do Rio Grande do Sul. Programa de Pós-Graduação em Geologia, Universidade Federal do Rio Grande do Sul, Tese de Doutorado, 208 p.

Scherer, C.M.S.; Faccini, U.F. \& Lavina, E.L. 2000. Arcabouço estratigráfico do Mesozóico da bacia do Paraná. In: M. Holz, \& L.F. De Ros (eds.) Geologia do Rio Grande do Sul, UFRGS/ CIGO, p. 335-374.

Schneider, R.L.; Mülhlmann, H.; Tommasi, E.; Medeiros, R.A.; Daemon, R.F. \& Nogueira, A.A. 1974. Revisão estratigráfica da bacia do Paraná. In: CONGRESSO BRASILEIRO DE GEOLOGIA, 25, 1974. Anais, Porto Alegre, SBG, 1:41-65.

Soares, P.C. 1975. Divisão estratigráfica do Mesozóico no Estado de São Paulo. Revista Brasileira de Geociências, 5:229251.

Turner, S.; Regelous, M.; Hawkesworth, C. \& Montovani, M. 1994. Magmatism and continental break-up in the South Atlantic: high precision ${ }^{40} \mathrm{Ar}-{ }^{49} \mathrm{Ar}$ geocronology. Earth and Planetary Science Letters, 121:333-348.

Voigt, E. 1960. Uber einen mutmasslichen fossilen Harnstein (Urolith) aus der Oberen Kreide. Mitteilungen aus dem Geologischen Staatsinstitut Hamburg, 29:85-95. 